\title{
Sylvatic Trichinella reservoir not found among voles in Finland
}

\author{
Hanna Välimaa1*, Jukka Niemimaa², Antti Oksanen, Heikki Henttonen² \\ From Parasite infections of domestic animals in the Nordic countries - emerging threats and challenges. \\ The 22nd Symposium of the Nordic Committee for Veterinary Scientific Cooperation (NKVet) \\ Helsinki, Finland. 7-9 September 2008
}

\section{Background}

Sylvatic Trichinella infection has been found to be very common in Finnish wild carnivores [1], especially locally in Southern and partly Central Finland. Cannibalism and carrion feeding have been regarded as the major source of infection to red foxes and raccoon dogs. Voles have been found the major food items of red foxes [2]. They are regarded as herbivorous, but many herbivores consume animal tissues occasionally. Therefore, voles might be assumed potentially to take part in Trichinella life cycle in the wild. Microtus spp and Myodes spp have been found to be infected with Trichinella, e.g. [3]. In Finland, refuse tip rats have been found to be rather commonly infected with Trichinella spiralis [4].

\section{Material}

A total of 1761 bank voles Myodes glareolus, and 138 field voles Microtus agrestis, trapped on 30 transect sampling locations in Finland. In addition, also 60 shrews, Sorex spp. accidentally found succumbed in the traps, were also included in the study. After killing, during dissection, the right hind leg of each animal was removed and frozen until thawed at laboratory. Left hind legs were spared for confirmation analyses. Following thawing, the legs were treated as meat inspection samples according to Commission Regulation (EC) No 2075/2005 utilizing pepsin- $\mathrm{HCl}$ digestion.

\section{Results and discussion}

No Trichinella spp larva was found in any of the samples. Therefore, microtid rodents in Finland cannot be confirmed to take part of the Trichinella spp life cycle. The opposite cannot be confirmed, either, as absence of evidence is not equal to evidence of absence. The predilection sites of Trichinella muscle larvae in microtid rodents are not well-known. Perhaps the right hind leg is not a good matrix for Trichinella larvae. In addition, even though the material consisting of 1899 small mammals may appear large at topical inspection, the potential impact of microtid rodents on Trichinella transmission biology is based on the high numbers of animals. The Finnish vole population fluctuates all the time, but during the peaks there are estimated to be about 200000000 voles in the country.

\section{Author details}

${ }^{1}$ Finnish Food safety Authority Evira, Fish and Wildlife Health Research Unit (FINPAR), Oulu, Finland. ${ }^{2}$ Finnish Forest Research Institute, Vantaa Research Unit, Finland.

Published: 13 October 2010

\section{References}

1. Oivanen L: Endemic trichinellosis - experimental and epidemiological studies. Dissertation 2005, Yliopistopaino, Helsinki.

2. Dell'Arte GL, Laaksonen T, Norrdahl K, Korpimäki E: Variation in the diet composition of a generalist predator, the red fox, in relation to season and density of main prey. Acta Oecologica 2007, 31:276-281.

3. Holliman RB, Meade BJ: Native trichinosis in wild rodents in Henrico County, Virginia. J. Wildl. Dis 1980, 16:205-207.

4. Mikkonen T, Valkama J, Wihlman H, Sukura A: Spatial variation of Trichinella prevalence in rats in Finnish waste disposal sites. J. Parasitol 2005, 91:210-213.

doi:10.1186/1751-0147-52-S1-S15

Cite this article as: Välimaa et al:: Sylvatic Trichinella reservoir not found among voles in Finland. Acta Veterinaria Scandinavica 201052

(Suppl 1):S15

${ }^{1}$ Finnish Food safety Authority Evira, Fish and Wildlife Health Research Unit (FINPAR), Oulu, Finland

Full list of author information is available at the end of the article 